However, machines can never displace mathematical thought. A characteristic of mathematical thought is its boldness, its imaginative power. Such creative mathematics, which at times finds no immediate application in technical science, has always found fertile ground in our Academy; and its development must continue on a broad scale. Such subjects as non-Euclidean geometry, the tensor calculus and the theory of groups, which seem to be abstract studies absolutely cut off from life and from reality, nevertheless suddenly assume a decisive significance at definite stages of scientific development.

This explains the inclusion in the Academy's plan of the problems of the theory of numbers, abstract algebra, topology and mathematical logic.

\title{
QUERIES
}

24. Integral of a Struve Function.-In a problem of diffraction the following integral comes up: $\int_{0}^{x} H_{0}(t) d t$. Where may I find a published table of this integral for the range $x=[0(.1) 10 ; 6 \mathrm{D}]$ ?

\section{W. Horton}

Defense Research Laboratory

University of Texas

EDITORIAL Note: Since we received this Query for publication there came from Dr. JohN W. WRENCH, JR., a copy of a table of $\int_{0}^{x} H_{0}(t) d t, x=[.1(.1) 10 ; 8 \mathrm{D}]$. This was obtained by numerical integration of the values of $H_{0}(x)$ tabulated in G. N. Watson, $A$ Treatise on the Theory of Bessel Functions, second ed., Cambridge and New York, 1944, p. 666-684. For integral values of the upper limit the integral was calculated to about 15D by infinite series. This check on certain of the entries indicates that the maximum error in any entry should not exceed $0.6 \times 10^{-8}$.

25. Russian Bessel Function Tables.-According to an advertisement in Matematicheskit Sbornik, v. 51, no. 3, 12 June 1941, the Mathematical Institute of the USSR Academy of Sciences was at this time in 1941 about to publish a volume entitled Tablitsy Besselevykh Funktsit Mnimogo Argumenta [Tables of Bessel Functions with Complex Argument]. It was announced that the volume contained about 400 pages and was to cost 25 roubles. The Library of Brown University has long but vainly tried to procure a copy. Can any reader report on the ownership of this volume of tables by any individual or library, or on a copy for sale?

R. C. A.

\section{QUERIES-REPLIES}

33. Portraits and Biographies of British Mathematical Table MAKERS (Q21, v. 2, p. 286).- - Herewith are submitted references to biographical material concerning four of these table makers. (a) PETER BARLow: Amer. Acad. Arts \& Sci., Proc., v. 6, 1866, p. 15-16; Inst. Civil Engin., Proc., v. 22, 1863, p. 615-618; R.A.S., Mo. Not., v. 23, 1863, p. 127-128; R. Soc. London, Proc., v. 12, 1863, p. xxxiii-xxxiv. Sir Humphry Davy, Six Discourses, London, 1827, p. 111-115, also in H. Davy, Coll. Works, v. 7, London, 1840, p. 76, 83-89. (b) Richard FARLey: R.A.S., Mo. Not., v. 40, 1880, p. 192-194. (c) HIRSCH FILIPOwsKI: Jewish Encyclopedia, v. 5, New York, 1903, p. 383 (M. BeEr). (d) Peter Gray: R.A.S., Mo. Not., v. 48,1888 , p. $163-165$.

JEKUTHIEL GINSBURG

Yeshiva University

New York City 
Henry Briggs: Since Karl Pearson made his inquiries (on my behalf) about a portrait, in 1924, I have made searches at the British Museum and the National Portrait Gallery and elsewhere, and am forced to the conclusion that no portrait exists. JAmes Dodson: Inst. Actuaries, Jn. and Assurance Mag., v. 14, 1867-68, p. 341 (A. DE MORGAN).

\section{A. J. Thompson}

Southwood, Waller Lane

Caterham, Surrey, England

Editorial Note: Of those mentioned above, the Dict. Nat. Biog. contains sketches of the following: (i) BARLOw, v. 3, 1885, p. 222-224 (A. M. CLERKE); (ii) BRIGGS, v. 6, 1886, p. 326-327 (T. WhITTAKER); (iii) Dodson, v. 15, 1888, p. 174-175 (G. J. GRAY); (iv) Gray, v. 23, 1890, p. 16 (G. GoODWIN); there are also sketches of Gray in C. WALFORD, Insurance Cyclopaedia, London, v. 5, 1878, p. 540-541, in Inst. Actuaries, Jn., v. 26, 1889, p. 301-302, 406, and in Intern. Insurance Encyclopedia, New York, 1910, p. 329-330. For Dodson, see also Int. Ins. Encycl., p. 227, and WALFORD, Ins. C., v. 2, 1873, p. 390-391. There are also sketches of Filipowski, mathematician, linguist, editor, in Walford, Ins. C., v. 3, 1874, p. 296-297 (not an F. R. S. as here stated), in Jüdisches Lexikon, v. 2, Berlin, 1928 (KaRL KARPELESZ), and in Universal Jewish Encyclopedia, New York, v. 4, 1941, where the name is given as "Zebi Hirsch Filipowski." In his $A$ Table of Anti-Logarithms . . ., London, 1849, and second ed. rev. and corrected, London, 1851, the name appears as Herschell E. Filipowski. Herschell Filipowski is also the form of name used in 1857 in his English edition of Napier's Wonderful Canon. Hence Herschell E. Filipowski (used also by Walford and by the British Museum Catalogue) appears to be the proper form of his name in connection with mathematical publications. In his edition of F. BAILY, The Doctrine of Life-Annuities and Assurances, London, 2 v., 1864-1866, the name is simply H. Filipowski. We have not discovered for what name the E. may stand. Herschell, Hersh and Hirsch are all names, meaning "deer" or "stag," for which Zebi is the Hebrew word. The repetition Zebi Hirsch is common among Jews (like Abba Father in the Bible).

\section{CORRIGENDA}

V. 2, p. $336,1.9$, for 348 read 384 ; p. $356,1 .-1$, for by the relays, read by the same relays; p. 368,1 . 10, for 1940 , read 1946 ; p. $375,1 .-1$, for 342 , read 242 . 